BJHS: Themes 3: 105-128, 2018. C British Society for the History of Science 2018. This is an Open Access article, distributed under the terms of the CreativeCommons Attribution licence (http://creativecommons.org/licenses/by/4.0/), which permits unrestricted re-use, distribution, and reproduction in any medium, provided the original work is properly cited.

doi:10.1017/bjt.2018.4 First published online 12 April 2018

\title{
Science in The Children's Encyclopedia and its appropriation in the twentieth century in Latin America
}

\author{
BERNARDO JEFFERSON DE OLIVEIRA*
}

\begin{abstract}
In the early twentieth century, encyclopedias addressed to children and youths became special reference works concerning science and technology education. In search of greater comprehension of this historical process, I analyse The Children's Encyclopedia's representation of science and technology, and how it was re-edited by the North American publishing company that bought its copyrights and promoted its circulation in several countries. Furthermore, I examine how its contents were appropriated in its translations into Portuguese and Spanish, which circulated in Latin America in the first half of the twentieth century. The comparison between the different versions reveals that the writings of science and technology are practically the same, with significant changes only in literature and in the approach of historical and geographical themes. I then argue that, even keeping the scientific contents virtually unchanged, these versions of the encyclopedia gave it a new meaning, because of the contexts in which they circulated. Finally, I show how the appropriations of the encyclopedia contributed to the promotion of scientific values and technological innovation as the core development and as a model of civilization for South American nations.
\end{abstract}

'Someone who spends fifteen minutes a day in reading the pages of this encyclopaedia would know after three years more about the earth and the life on it than the wisest men knew a few generations ago'. So testified the president of the college of the City of New York, John H. Finley, in the introduction to The Book of Knowledge/The Children's Encyclopedia. This encyclopedia circulated in many parts of the world and represented science and children as heirs of the past and the promises of the future.

The spread of science depends not only on good ideas, but also on being convincing, which means capturing attention, persuading people about its importance and efficacy, circulating opinions, stabilizing some institutions and their authority and taking them for granted, while educating new generations. As has been pointed out by several authors, many methods have been used with the purpose of popularizing science, trying to make it accessible to everyone: lectures, conferences, courses, magazines, books, encyclopedias, exhibitions, museums, botanical and zoological gardens,

\footnotetext{
* School of Education, Universidade Federal de Minas Gerais. Av. Antonio Carlos 6627, Belo Horizonte, MG 30260-280, Brazil. Email: bjo@ufmg.br.

This research was funded by the Brazilian National Research Council (CnPq) and Fapemig.
} 
cinema, radio, and television. ${ }^{1}$ Even if not coherently, all of these methods interact, with mutual references and reinforcements, and understanding this process is vital for comprehension of an emerging public view of science.

As noted by Myers, the popularization of science has shaped non-scientists' knowledge more than the original works of scientists. ${ }^{2}$ Popularization is not simply the transmission or the watering down of scientists' ideas. Scientific knowledge itself is transformed, because it is put in new textual forms and into new relations with other elements of non-scientific culture. One of the reasons given to account for how popularized science propagated among different classes and social groups is the supposed universality of knowledge, the conception of science as 'natural laws' that transcend national boundaries and cultural diversity.

The dissemination of scientific knowledge has generally been treated as a process in which 'universal knowledge' produced in advanced centres is transmitted to 'lagging peripheries'. The universal validity of scientific laws, based on the objectivity of the scientific method, is often used to support this vision. However, criticism of the idea of universal knowledge as being true anywhere has reinforced the need to analyse this construction and its historical and local appropriations. Here I will take the perspective that regards translations and spread of knowledge as a fundamental mechanism for the stabilization and wide acceptance of practices and knowledge. Pestre's formula provides a good summary of this approach's implicit inversion: if scientific knowledge (as well as other forms of knowledge) circulates, this is not because of its putative universality; rather it is precisely because it circulates, or in other words because it is (re)used in other contexts and others assign it meaning, that it is described as universal. ${ }^{3}$

This methodological perspective is coupled, in my view, to Burke's idea that translations almost always involve decontextualization and recontextualization. ${ }^{4}$ Therefore they should not be addressed as processes of loss (leading to misunderstandings and corrupting the original), but rather as re-creations, in regard to what they select and discard

1 See, for instance, Stephen Hilgartner, 'The dominant view of popularization: conceptual problems, political uses', Social Studies of Science (1990) 3, pp. 519-539; Marcel Lafollette, Making Science Our Own: Public Images of Science 1910-1955, Chicago: The University of Chicago Press, 1990; Roger Cooter and Stephen Pumfrey, 'Separate spheres and places: reflections on the history of science popularization and science in popular culture', History of Science (1994) 32, pp. 237-267; Bruce Lewenstein, 'Communiquer la science au public: L'émergence d'un genre américain, 1820-1939', in Bernadette Benseaude-Vincent and Anne Rasmussen (eds.), La science populaire dans la presse et l'édition, Paris: Editions du CNRS, 1997, pp. 143-153; Jane Gregory and Steven Miller, Science in Public: Communication, Culture, and Credibility, Cambridge, MA: Basic Books, 1998. Bernardette Bensaude-Vincent, 'A genealogy of the increasing gap between science and the public', Public Understanding of Science (2001) 10, pp. 99-113; Jonathan Topham, 'Rethinking the history of science popularization/popular science', in Faidra Papanelopoulou, Agusti Nieto-Galan and Enrique Perdiguero (eds.), Popularizing Science and Technology in the European Periphery, 1800-2000, Aldershot: Ashgate, 2009, pp. 1-10; Andreas Daum, 'Varieties of popular science and the transformations of public knowledge', Isis (2009) 100, pp. 319-332.

2 Greg Myers, 'Discourse studies of scientific popularization: questing the boundaries', Discourse Studies (2003) 2, pp. 265-279.

3 Dominique Pestre, 'Por uma nova história social e cultural das ciências: novas definições, novos objetos, novas abordagens', Cadernos IG-Unicamp (1996) 1, pp. 3-56.

4 Peter Burke and Ronnie Po-Chia Hsia (eds.), A tradução cultural nos primórdios da Europa moderna, São Paulo: Unesp, 2009. 
from the particularities of the original context, or for what they conjugate and balance out as they are recontextualized. Gavroglu et al. have shown how this process can be taken as one of appropriation, since these recontextualizations and their circulation serve local interests and reinforce certain cultural perspectives. ${ }^{5}$ Here, I seek to address the circulation of The Children's Encyclopedia and some of its appropriations involving, among other things, the selection, translation, recontextualization and advertising strategies used to reach and mobilize different audiences - as a key element for the universalization of science and technology.

\section{The publishing history of The Book of Knowledge/The Children's Encyclopedia}

Since the eighteenth century, there has been a strong correlation between the growth of scientific knowledge and the multiplication of encyclopedias, most of which have given an important place to science and technology. ${ }^{6}$ Although there is a long history of this kind of book before the modern era, it was only in the eighteenth century that they began to sell well. Diderot and d'Alembert's editorial enterprise is a landmark and one of the best-known products of the Enlightenment. Their Dictionaire raisonné des sciences, des arts et des métiers, as well the Encyclopaedia Britannica, represents the ideas of the Enlightenment movement: to empower citizenry and promote knowledge, making it accessible to every interested citizen.

Most of the encyclopedias were primarily concerned with the collection of knowledge in a manageable form. One of their innovations was the lack of a hierarchical structure; nevertheless, they reordered and reinforced the divisions within knowledge. During the eighteenth and nineteenth centuries, systematic schemes were generally abandoned in favour of alphabetical organization.

Although they had been revolutionary in legitimizing and circulating scientific and technological knowledge, those early encyclopedias were not yet the mass media that they became in the twentieth century, when improvements in the accessibility of their language, large-scale production, transnational editorial companies, and armies of well-equipped sellers reached a vast new layer of consumers. Taking into account the number and education of their readers, twentieth-century popular encyclopedias can be compared to popular magazines considered 'low culture', apart from the fact that many of these encyclopedias, such as the case we focus on here, targeted mainly children, a group that eludes the usual economic/cultural class classifications. Other kinds of scientific readings for children had circulated during the eighteenth and nineteenth centuries, such as the scientific dialogues analysed by Secord, Myers and Fyfe. ${ }^{7}$ As has been

5 Kostas Gavroglu, Manolis Patiniotis, Faidra Papanelopoulou, Ana Simões, Ana Carneiro, Maria Paula Diogo, José Ramón Bertomeu Sánchez, Antonio García Belmar and Agustí Nieto-Galan, 'Science and technology in the European periphery: some historiographical reflections', History of Science (2008) 152, pp. 153-175.

6 Richard Yeo, Encyclopaedic Visions: Scientific Dictionaries and Enlightenment Culture, Cambridge: Cambridge University Press, 2001.

7 James Secord, 'Newton in the nursery: Tom Telescope and the philosophy of tops and balls, 1761-1838', History of Science (1985) 23, pp. 127-151; Greg Myers, 'Science for women and children: the dialogue of 
pointed out, this genre of literature is very significant in the analyses of popular representation of science because, traditionally, only secure and safely established knowledge has been deemed suitable for children.

The Children's Encyclopedia was originally edited by Arthur Mee (1875-1943), working for the English publisher Alfred Harmsworth (Amalgamated Press). It was first issued in Great Britain as a fortnightly magazine between March 1908 and February 1910. By 1908, Arthur Mee was a successful young journalist from Nottingham, described as 'torrentially productive'. He came from a Nonconformist, Baptist background. A strong defender of abstinence from alcohol, tobacco and blood sports, he shared with his boss, Harmsworth,

an unchanging belief in the Christian way of life, a deep love of this native land, the conviction that the British Empire had been a source of great good for humanity, an anxious concern for the welfare of the rising generation, hero worship, and a deep inner joy in the task he set himself. ${ }^{8}$

Besides writing for several newspapers and magazines (Morning Herald, Daily Mail, TitBits), Mee wrote Nonconformist pamphlets and biographies. Most of these writings served as the basis for the children's books he published later. These books, which gave Mee great fame and fortune, were an amalgam of texts from the fortnightly magazines he worked for as editor and published by Alfred Harmsworth (later Lord Northcliffe). Harmsworth's press had revolutionized the market with radical changes in the economic basis of newspapers. ${ }^{9}$ Its magazines - Harmsworth Self-Educator, The Children's Encyclopedia, My Magazine - had an incredible success before becoming collections of books.

By 1910, The Children's Encyclopedia was reissued in book format in a set with eight volumes. The editorial reorganization, which has had many editions and translations since, was made in the United States by a team led by Walter M. Jackson, who renamed it The Book of Knowledge, preserving The Children's Encyclopedia as a subtitle, and increasing its size to twenty volumes, with the addition of more text and many images. ${ }^{10}$

W.M. Jackson and his North American company, the Grolier Society, were the great entrepreneurs of The Book of Knowledge/The Children's Encyclopedia not just for the American continent, but also for China and some European countries. ${ }^{11}$ The Italian $\mathrm{La}$ Enciclopedia dei Ragazzi, the French Qui? Pourquoi? Et Comment?, and the Russian

popular science in the nineteenth century', in John Christie and Sally Shuttleworth (eds.), Nature Transfigured: Science and Literature, 1700-1900, Manchester: Manchester University Press, 1989, pp. 171-200. Aileen Fyfe, 'Young readers and the sciences', in Nicholas Jardine and Marina Frasca-Spada (eds.), Books and the Sciences in History, Cambridge: Cambridge University Press, 2000, pp. 276-289.

8 Roger Paulin, 'Heroes and villains: the case of Arthur Mee's Children's Encyclopedia', Bulletin of the John Rylands Library (2002) 3, pp. 161-170, 162.

9 John Alexander Hammerton, Child of Wonder: An Intimate Biography of Arthur Mee, London: Hodder \& Stoughton, 1949.

10 Arthur Mee and Holland Thompson (eds.), The Book of Knowledge/The Children's Encyclopedia, 20 vols., New York and London: The Grolier Society and The Educational Book Co., n.d.

11 His W.M. Jackson Inc. was a large editorial house in several Latin American countries. 
Dietskaia Entsiklopediia came out in the same decade. ${ }^{12}$ By the end of the 1920 s, the Spanish El Tesoro de la Juventud and the Portuguese O Tesouro da Juventude were already bestsellers in South America, while the Québecois L'enciclopédie de la jeunesse and the Chinese edition were on sale. ${ }^{13}$

By 1940, The Book of Knowledge/The Children's Encyclopedia had forty editions and had sold one and a half million sets in the British Empire and three and a half million sets in the United States. ${ }^{14}$ From 1966, it was published as The New Book of Knowledge, organized in alphabetical order. In the year 2000, Scholastic Corporation acquired Grolier and the rights to The New Book of Knowledge, which also had a digital version sold until 2007, but without the status it once had when it was sold from door to door and was displayed on the shelf as a symbol of cultural capital.

The considerable duration of the circulation of these magazines allowed for adjustments in language and in topics according to market feedback. Thus they were already well tested when they got into the book format. Consecutive reprints, extending the audience, were an important way of standardizing the common stock of knowledge. This process reinforced not just the values of science but also the authority of scientists. However, the process involved not just contributors and editors, but also publishing companies, translators, distributors, sellers and consumers, which implies a diversification of the authorship of these books. Considering the size of the investments and the network of professionals involved in editorial projects like this, as well as the recognition of diffusion and scientific education as components of science, perhaps the notion of big science should be expanded in order to incorporate large-scale global publishing and educational enterprises alongside the more usual cases of military-industrial-academic projects.

The extent of investments undertaken by some of these editorial enterprises made them very sensitive to market tastes, and willing to incorporate suggestions from the public. Revisions came after a shifting of ideas developed by the editors, parents, teachers, librarians and even children themselves. For instance, the co-editor of some of The Book of Knowledge/The Children's Encyclopedia editions, M.L. Norgaardread, would read the stories proposed for inclusion in the set to groups of children of various ages in order to check their real interest. ${ }^{15}$ Nevertheless, some of the original traces of Mee's writing and style were reinforced, such as the children's questions and the idolization of those scientists who performed golden deeds.

One of the key strategies used by the American publisher to diversify their readership was to offer slightly different products. Distribution and sale are easier when one first

12 The French Qui? Porquoi? Et Comment?, edited by Jean Terquem, and Dietskaia Entsiklopediia, edited by S. Kniaz'kov and I. Vagner (Moscow: Tipografiia t-va I.D. Sytina, 1913), seem to have been aborted by the First World War and the Bolshevik Revolution.

13 All we know about the Chinese edition is through advertisements in North American newspapers. We did not find copies of the encyclopedia, even in Chinese libraries.

14 The Grolier Society, The Story of The Book of Knowledge, New York: The Grolier Society Inc., 1946, p. 7.

15 \$ales \$ense (1960) 9, p. 3; Walter M. Jackson, Instrucciones a sus traductores y correctors, Buenos Aires: W.M. Jackson, Inc., 1945. 


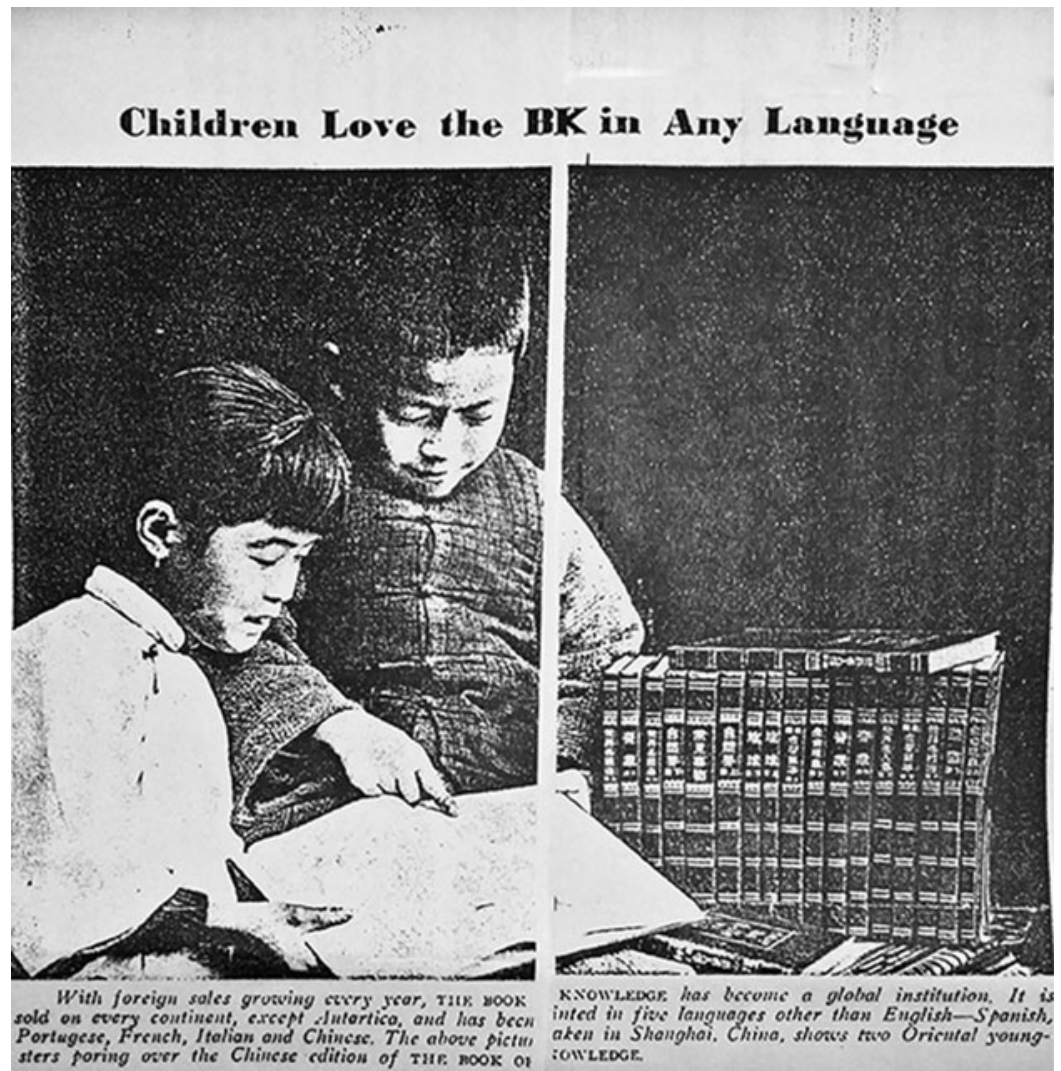

Figure 1. 'With foreign sales growing every year, the Book of Knowledge has become a global institution ... The above picture taken in Shanghai, China, shows two Oriental youngsters poring over the Chinese edition of The Book of Knowledge'. \$ales \$ense (1960) 9, pp. 10-11. \$ales \$ense (sic) was a newsletter of the Grolier Society Inc. The May 1960 issue was a commemorative fiftieth-anniversary edition of The Book of Knowledge.

product succeeds and the net of collaborators, distributors, sellers and consumers is settled. The same photographs and pictures, for instance, were used in different collections. Empowered by the huge sales of The Book of Knowledge, the Grolier Society bought the rights to publish other Harmsworth products as well as encyclopedias commercialized by other publishers. ${ }^{16}$

16 Doubleday's Encyclopedia, issued as Grolier Encyclopedia in 1944; Richards Topical Encyclopedia in 1944; The Encyclopedia Americana in 1945; Le Petit Informateur Canadien, 1950; Encyclopedia Canadiana, 1957; and, after 1960, American People's Encyclopedia, Our Wonderful World, The Children's Hour, Basic Home Library, Encyclopedia International, Grolier Universal Encyclopedia. 
Table 1. Description of subjects among the volumes

\begin{tabular}{|c|c|}
\hline Sections/books & Description \\
\hline 'The book of men and women' & Presents the great heroes and contributors of humanity \\
\hline 'The book of familiar things' & $\begin{array}{l}\text { Explains how things like locks, motors, ships, bridges, tunnels, } \\
\text { elevators, etc. are built and work }\end{array}$ \\
\hline 'The book of wonder' & $\begin{array}{l}\text { Offers a mix of curious questions, many of them written in a very } \\
\text { childish style and their answers in a simple but adult style, with a } \\
\text { great deal of information and definitions }\end{array}$ \\
\hline 'The book of nature' & $\begin{array}{l}\text { Covers what we call cosmology, astronomy, geology, botany and } \\
\text { zoology. In some editions, it is divided into 'The book of the Earth', } \\
\text { 'The book of plants' and 'The book of animals' }\end{array}$ \\
\hline 'The book of our own life' & Deals with biology and medicine \\
\hline 'Things to make and do' & $\begin{array}{l}\text { Teaches practical skills and suggests a range of activities to 'fill the } \\
\text { free time in a creative and enriching way'. A large part of this } \\
\text { section is dedicated to manual activities, generally divided between } \\
\text { those for boys and those for girls }\end{array}$ \\
\hline $\begin{array}{l}\text { 'The story of famous books' and } \\
\text { 'The book of stories' }\end{array}$ & $\begin{array}{l}\text { Contains abridged versions, which were supposed to encourage the } \\
\text { reader to take on the full texts }\end{array}$ \\
\hline 'The book of poetry' & $\begin{array}{l}\text { Presents many kinds of verse: sonnets, songs, odes, dramatic pieces, } \\
\text { hymns, psalms, lullabies, folk songs }\end{array}$ \\
\hline 'The book of all countries' & $\begin{array}{l}\text { Provides descriptions of the geography and history of many } \\
\text { countries. Separate are 'The book of the United States' and 'The } \\
\text { book of Canada', which address these two countries in more detail }\end{array}$ \\
\hline 'School lessons' & $\begin{array}{l}\text { Provides a basic introduction to music, the arts and the French } \\
\text { language and includes some topics in arithmetic, reading (short } \\
\text { texts with notes on how to interpret or dramatize it) and writing } \\
\text { (calligraphy) }\end{array}$ \\
\hline 'The golden deeds' & $\begin{array}{l}\text { Describes the actions of admirable 'heroes', but also the heroism of } \\
\text { 'simple and humble souls' }\end{array}$ \\
\hline
\end{tabular}

\section{The contents of the Encyclopedia and its representations}

There are some small variations in the names of the sections in the two different AngloAmerican editions I have examined: those of $c .1913$ and of $1946 .{ }^{17}$ Generally, subjects were grouped into sections (Table 1).

The question I now turn to is what, in the Encyclopedia, counted as science and what did not? First of all, sections were not grouped according to subjects, nor did they present a clear-cut boundary between themes. The articles of 'The book of nature' and 'The book of our own life' are usually about natural phenomena regardless of boundaries between disciplines. But aspects of science also occupy the book 'Things to make and do', which encouraged children to experiment, to build and use instruments of observation such as the microscope and measuring instruments, including the barometer, the anemometer and the rain gauge. In addition, many 'heroes' featured in 'The golden deeds' were scientists, inventors and explorers, men who 'made the world known', ranging from the first

17 Since there is no date printed in editions over the first two decades, we have estimated dates from the copyright records of the images and comparison of the information printed with historical facts. 
expeditions to the East and overseas journeys to the explorers of polar regions. The distribution of subjects in the first editions of the The Book of Knowledge/The Children's Encyclopedia can be quantified as follows: science/nature 43 per cent; art and literature 32 per cent; history and geography 18 per cent; technology 14 per cent; religion and mythology 3 per cent.

Comparing the indexes of the first editions with that of 1946, we can see that the space dedicated to scientific and technological matters increased by around 15 per cent over these four decades. Given that the The Book of Knowledge/The Children's Encyclopedia maintained its size, the extension of articles and the inclusion of new subjects imposed the exclusion or reduction of other sections, such as literature and history. In addition, the questions aroused and answered in 'The book of wonder' section were progressively more scientific. ${ }^{18}$ This is also true of the content of the Annual Book of Knowledge, a yearbook published after 1944 to be added to the encyclopedia. Although a large part of the content of 'The book of wonder', 'Men and women', 'Golden deeds', 'Things to make and do' and 'Familiar things' had no direct connection with scientific or technological matters, they were nevertheless important as educational mediators. In order to understand the values historically embodied in the public view of science, we should not dissociate the approach to scientific knowledge from the way the scientific heroes were described or from what the encyclopedia represented as 'golden deeds'.

No section was ever collected into a unique volume. On the contrary, they were dispersed within volumes, and that arrangement was considered quite confusing even if later it was recognized as part of the encyclopedia's success. Perhaps the mixed presentation was seen as more entertaining. No one would become bored if every five pages a completely new topic appeared.

The Book of Knowledge/The Children's Encyclopedia's articles were vividly written and profusely illustrated (ten thousand pictures in the first years' editions and fifteen thousand after 1925), ${ }^{19}$ especially for the period. The information about its quantity of images appears in several advertisements that boast of their proportion and justify their importance. According to one of these ads,

The royal road to learning today is the picture road. It is stated on good authority that motion pictures will soon supplement the textbooks in the schools. Pictures speak louder than words. The eye is the first and greatest teacher and the child can grasp an abstract truth or a scientific fact at once if he sees it illustrated by striking and attractive pictures.

According to another advertisement in the New York Times, 'this encyclopaedia is arranged according to the psychology of the child's mind, in articles of just the right length to hold and not weary the attention, and with a variety in arrangement which

18 The introduction of The Book of Knowledge, 1946 edition, stated, 'we are all scientists today, in a big or little way, for we live in a world of scientific marvel'. Hence the presentation of the wonder questions section says, 'the questions are answered scientifically, in simple words'.

19 New York Times, 17 April 1920, p. 13. The newsletter \$ales \$ense affirms that the illustrations became so important that it 'was not unusual to choose pictures first and write the text around them'. \$ales \$ense (1960) 9 , p. 3. 
keeps the child constantly reading without becoming fatigued' ${ }^{20}$ Images are very helpful in explanations, avoiding descriptions that are too abstract for children. Photographs made those images more alive and reduced the old paradox of encouraging direct observation through reading. The editors also avoided all technicalities and scientific terms in the texts.

If it did not have a thorough index at the end, The Book of Knowledge/The Children's Encyclopedia could not have been used as a conventional reference library as it largely was; although whoever reads the tutorial booklet distributed for educators to use this encyclopedia - Parents' and Teachers' Guide to Reading Courses - will realize that the arrangement of the subjects was well contrived. This booklet furnished 'parents and teachers with an analysis of each of the Great Departments of knowledge, which this work comprehends and which the index naturally does not reveal, or the psychological arrangement permit'. ${ }^{21}$ There was a logical order of development behind the hazardous sequence of the items within each volume. To give an example, animal life is spread over volumes 1 to 4 ; birds, 5 to 7 ; fishes, 8 to 9 ; insects, 9 to 11 ; and so on. In some editions, there was a tiny reference (half the size of the page number) at the end of the topic indicating to the reader the number of the page with more content related to the subject. Some editions of the encyclopedia did not even use this expedient. The general index at the end of the last volume must have been very much used by readers looking for a specific subject. On the other hand, possibly many readers leafed through the pages of the encyclopedia, treating it like a magazine, attracted to a specific article by a particular image or by curiosity.

Why did the editors arrange the book in this way? As we mentioned above, most other encyclopedias were organized either alphabetically or thematically. Each of these systems had its advantages: alphabetization might make it easier to find the topic wanted and did not depend on a systematic vision. Hence such works looked more impartial concerning hierarchies of knowledge and their correlation and development. On the other hand, thematic organization may have been seen to fit better with the methodical 'spirit of science'.

The methodical character of science was one of the major appeals in the legitimation of the scientific enterprise. Accessible to laymen and capable of being extended beyond the study of nature, the scientific method has been considered an essential tool to promote citizenship and betterment of life. Therefore a common argument in the advocacy of scientific literacy has been the methodical disposition implied in scientific culture. The alphabetical or thematic order explores what is supposed to be the internal logic of rational cognition. Nonetheless, The Book of Knowledge/The Children's Encyclopedia focused on the primacy of the subjectivity of the experiencer. Instead of method, what best expressed science was to be its wonder. One of the questions included in The Book of Knowledge/The Children's Encyclopedia gives us the argument for this kind of disposition: 'Can we think about things that do not interest us?' And the answer is:

20 New York Times, 17 April 1920, p. 13; 27 January 1924, p. SM16.

21 Grolier Society, Parents' and Teachers' Guide to Reading Courses - The Book of Knowledge, New York: The Grolier Society, 1917, p. 1. 
'No. It is the interest that starts us thinking. ${ }^{22}$ The editors bet on the 'irresistible attraction' of science and technology and took on the task of 'getting an education as delightful as it ought to be'. ${ }^{23}$ They were conjoining an important educational movement of the time that inaugurated a perspective on science education, called progressive or active schooling. This movement had its beginnings in Europe in the nineteenth century and was especially strong in America in the first half of the twentieth century. Its main points were the need to make school enjoyable and meaningful to the student; lifelong learning, in addition to the scientific perspective, emphasized the doing. Some other aspects of progressive schooling diverged from the approach adopted by The Book of Knowledge/The Children's Encyclopedia, but all in all converged on the same childcentred education perspective, which placed importance on learning to learn and keeping the interest continuously extended.

Contrary to other Mee publications, such as the Self-Educator magazine, where what counted was not the wonder of knowledge but the need to have a job, to fix a leak or build a house, in The Book of Knowledge/The Children's Encyclopedia curiosity was the flame to keep alive: 'Curiosity is the greatest teacher'; 'Through curiosity Columbus discovered America. Every child has the capacity to discover a new world, if you will help him. ${ }^{24}$ Parents, uncles, aunts and teachers were also addressed by and read The Book of Knowledge/The Children's Encyclopedia. The message in the publicity and the explanatory booklet was that all are responsible to be prepared to give not disappointing answers but always stimulating ones.

Advertising in local newspapers was essential in selling and diffusing some of the values embodied in the The Book of Knowledge/The Children's Encyclopedia. Grolier's advertisement usually offered to those who wanted more information a free booklet with a sample of the questions, texts and pictures. Ads spread the value of attaining scientific knowledge and presented it as a worthy investment for child rearing. Even those who would not buy the product could learn about its advantages. Such advertisements had an important role in developing a consumerist culture for a growing scientific and industrial society.

Of course this kind of publicity was not the only way of circulating the need for The Book of Knowledge/The Children's Encyclopedia and its values. Examples and suggestions made by other promoters, like teachers, libraries and other parents, might be even more effective. Furthermore, there was an army of thousands of encyclopedia sellers knocking at every door with samples and a cunning sales pitch, arguing for the need to follow the advances of science and distinguish its new devices. Information about the concurrent World Book lets us estimate that the number of sellers surpassed six thousand. Although the advertisements emphasized the continuous updating of each new edition, most of the articles were practically unchanged. Instead, the changes were mainly in the order of the articles and in replacing old images with new ones.

22 The Book of Knowledge, op. cit. (10), c.1920, p. 5081.

23 Grolier Society, op. cit. (14), p. 7.

24 New York Times, 12 October 1921, p. SM13, ProQuest Historical Newspapers. 


\section{Curiosity-The Greatest Teacher}
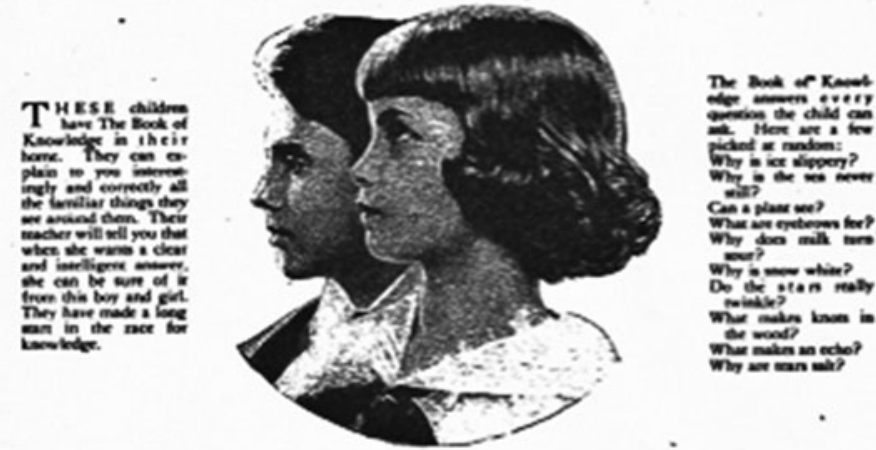

\section{Do You Know Why \\ TheBOOK of KNOWLEDGE}

Captures' the Child's Mind?

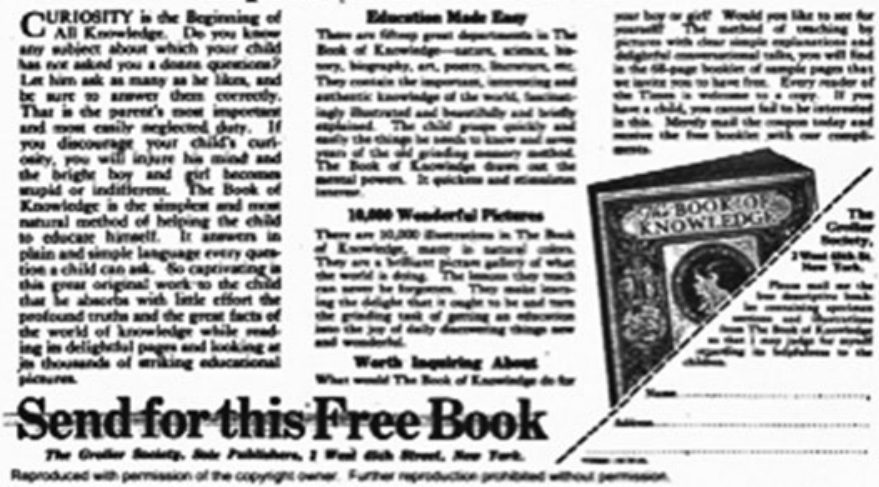

Figure 2. 'Let your child ask as many questions as he likes, and be sure to answer them correctly ... The method of teaching by pictures with clear simple explanations and delightful conversational talks you will find in the booklet of sample pages that we invite you to have free'. New York Times, 28 October 1923, p. SM13.

In the 'Book of wonder' section, the sequence of questions was not systematic or gradual, as used to be the case in nineteenth-century textbooks and catechisms, as for instance in Ackermann's and Pinnock's, where astronomy, algebra and natural history were structured as a series of short and less dramatized questions and medium-length 
answers containing a large amount of condensed information about each field, forming different chapters. ${ }^{25}$ In contrast, in The Book of Knowledge/The Children's Encyclopedia questions were crucial to arousing interest and not primarily progressive learning. Following the question 'How far off is the sky?' for instance, one will find 'How does oil make a rough sea calm?' Thus, while in the catechism's scheme the learning is supposed to work progressively by acquisition of successive information and impressions, in The Book of Knowledge the reader is expected to jump to other sections and focus on whatever looks interesting. The ways of forwarding or building the mosaic are conceived as idiosyncratic, with the assumption that this will not make much difference to attaining the the final result: a wonder and understanding of general knowledge. Once reading is practised every day a little, the understanding and disposition to further learning will be developed. Although the dialogues are impersonal, the tune of the questions and answers suggests clearly that any other young reader could raise similar questions and would receive answers from parents and teachers. In the advertising, the answers are said to be not just adequately but scientifically elaborated: 'Hundreds of questions, taken directly from the children's own lips, have been answered with scientific accuracy and a perfect simplicity', and in conformity with 'the latest psychology'. ${ }^{26}$

The wonder of science was identified with children's wonder, so both science and children were identified as the heirs of all achievements from the past and the promises of the future. Therefore one of the encyclopedia's slogans was 'Those who wonder shall reign!' 27 What was originally aimed at children was transposed to a more adolescent audience in foreign editions: juventud in the Spanish edition, juventude in the Portuguese, ragazzi in the Italian. And in fact the children that featured in the Book of Knowledge's imagery appear to be between eight and twelve years old. Even if some subjects, such as classical stories, were adapted in language convenient for kindergarten kids and several volumes contained nursery jingles, other entries like 'Energy from atoms' would hardly have been read even by young teenagers. ${ }^{28}$ This discrepancy, however, can be interpreted as flexibility in catering to different audiences.

Likewise, natural history possesses strong attractions for a juvenile audience, especially if presented visually. Nevertheless, some questions, such as the origins of species, were more challenging. The Book of Knowledge/The Children's Encyclopedia

25 Eugenia Roldán Vera, The British Book Trade and Spanish American Independence: Education and Knowledge Transmission in Transcontinental Perspective, Aldershot: Ashgate, 2003.

26 New York Times, 13 December 1913, p. 15.

27 Probably taking schoolteachers and librarians as allies, Finley indicates that, though The Book of Knowledge gives youth possession of the whole cycle of existence and circle of truth, it was not a substitute for textbooks and should be taken as supplementary reading which would help schoolteaching either at home or in libraries. Since the 1920s, The Book of Knowledge was rivalled by The World Book, which better fit the traditional pattern of the reference book. The World Book, the first edition of which appeared in 1917, was a substantial adaptation of the Practical Reference Library, published in 1907. See Willian Murray, Adventures in the People Business: The Story of The World Book. Chicago: Field Enterprises Educational Corporation, 1966.

28 'Energy from atoms' article written by the physicist and historian of science Gerald Holton, who later extended some of the works he had done for The Book of Knowledge 1946 edition and published as History of Sound under a pseudonym. See Bernardo J. Oliveira and Olival Freire Jr, 'Uma conversa com Gerald Holton', Caderno Brasileiro de Ensino de Física (2006) 23, pp. 315-328. 
used both approaches, probably with the aim of targeting readers with different ages and interests. Controversial issues such as evolution received a favourable but cautious treatment. Thus, after a lengthy presentation dealing with the origins of the ideas and the main points of both Darwin's and Wallace's theories, the article titled 'Famous men of science' remarked that 'many men of science ridiculed Darwin's theory; many attacked it as irreligious. Today, almost a hundred years later, Darwin's theory is accepted by many scientists, questioned by others, accepted with reservations by still others'. ${ }^{29}$ Such nuance may have helped its reception amongst religious leaders, whose approval was underlined in the publicity of the newspaper over the publication's first years. ${ }^{30}$

Concerning the authority of knowledge, readers were told that 'the only authority in science is Nature itself, and everything that men say, however great they are, must be tested'. ${ }^{31}$ However rhetorical this assertion might be, it reinforced the importance of neutral observation and experiment, instead of relying blindly on parents' and teachers' knowledge.

Concerning the construction of the authority in scientific dialogues for children, Myers points out a contradiction that can be seen in The Book of Knowledge: 'The books profess to teach learning by experience, but actually they teach learning from authority. They profess to value the learner's process, but they present this process in a closed world of knowable answers.' 32 In fact, although supportive of self-education, reference to traditional authoritative institutions like universities was abundant. Almost every mention of a scientist is followed by his or her university affiliation, where, readers were led to believe, science had been developed. Even Arthur Mee fancied a suggestive subtitle in the North American editions: his office address was displayed as an academic status. ${ }^{33}$

Concerning the image of science, there is a tension between what is described and what is suggested. The true science is described as pure, fundamental, and not applied:

The scientist never worries whether what he does today will build a better automobile tomorrow, or next year. He does not have to worry about such practical matters, for he knows that if he helps to add a little to all the things we know about nature, then, in the end, what he has done will some day help mankind to live a happier life. ${ }^{34}$

Accordingly, according to the encyclopedia, what moved scientists in their work was curiosity and the fact that they are not expected to worry about practical matters. More

29 The Book of Knowledge, op. cit. (10), c.1920, p. 870.

30 One common publicity strategy was to list names of famous readers and recommenders, among which is an expressive number of Jewish and Catholic leaders and religious newspaper editors.

31 The Book of Knowledge, op. cit. (10), c.1920, p. 728.

32 Myers, op. cit. (2), p. 181.

33 "When I was co-operating with Jackson in preparing the first American edition of the Children's Encyclopedia, he asked me if its editor had any university degrees, or had received an honorary doctorate, as the American public "rather set store on those things" ... And when he said in that case [a negative answer] he would put on the title-pages of the Book of Knowledge "Edited by Arthr Mee, Temple Chambers, London" (the office address!). I thought he was joking. But he assured me that in America that would look as good as "M.A. (Oxon)"'. Hammerton, op. cit. (9), p. 132.

34 The Book of Knowledge, op. cit. (10), 1946, p. 7138. 
noticeable in the 1940s editions than in previous issues, mathematics and physics stood out as the top scientific disciplines. This hierarchy can be fully appreciated in the 1946 list of eminent scientists of the twentieth century, most of them alive then and winners of Nobel Prizes, where twenty-two are physicists, ten are chemists, six are biologists, five are physiologists and two are archaeologists. Explorers, inventors like Edison, physicians or surgeons like Walter Reed, presented as heroes of science in other sections, are not listed.

Whatever the reasons for cultivating science, whether for honouring past and present achievements or for investing in its progress, what counted in the end was its products. Advocacy of science was based on the comforts and practicality it brought, even if it took a very long time for its application in health or machinery to work for humankind. Practicalities were also reinforced by the kind of explanation given for theoretical elements. The effort to make scientific theories significant to the young or lay reader made every subject directly connected to daily life. Likewise, the overwhelming presence of inventions, devices and techniques suggested that it was not pure science that was most important or, at least, not a science for spiritual or moral improvement.

The promotion of the use of science was intended to further the progress of civilization. The Book of Knowledge's publicity gave a more restricted sense to the generally wide meaning of civilization: success. The values of self-improvement and intellectual and economic progress in life competition, combined with the advancement of scientific learning through The Book of Knowledge, were viewed as the safest way to increase the chances of personal success in the young readers' future lives. ${ }^{35}$

The characteristics that distinguished the scientists were predominantly moral (perseverance, honesty, courage, selflessness) rather than cognitive (curiosity, wonder, wisdom). Analysing English media science before the Great War, Broks argued that, while scientists were described in popular fiction as unemotional, mindless of everyday affairs, egocentric, cantankerous and pedantic, in the non-fiction magazines the virtues attributed to real scientists were more comprehensive than the corresponding list of vices of their fictional counterparts: prodigy, creativity, perseverance, selflessness, all in addition to their human and social qualities. ${ }^{36}$

The heroic endeavour, especially, was often used in The Book of Knowledge as a way to show how science contributed to civilization and how science was a valid route to virtue. In a section of the 'Golden deeds' named 'Some modern heroes of science', there is a good explanation of why scientists should be viewed as warriors (although depicted as heroes, scientists are not considered free from mistakes):

in the olden days men were called heroes only if they showed bravery on the battlefield ... Today, we know that disease and poverty and ignorance are just as truly enemies of mankind as any forces of land and sea. And because we know this, there is always a small army of devoted men ready to give up their lives to save their fellows from destruction. ${ }^{37}$

35 'Statistics tell us the story in the simplest form - If uneducated, he has a chance for success in 150,000; with a common school education, 4 chances; with a high school education, 87 chances; with a college education, 800 chances; with the book of knowledge in home, every chance'. New York Times, 17 April 1920, p. SM13, advertisement, ProQuest Historical Newspapers.

36 Peter Broks, Media Science before the Great War, New York: St Martin's Press, 1996.

37 The Book of Knowledge, op. cit. (10), 1946, p. 3235. 
It is noteworthy that combat against poverty was not mentioned elsewhere, unlike fighters against disease. One of the 'Golden deeds' topics was titled 'Martyrs to science' and told many cases of 'men and women who suffered so that mankind might live'. ${ }^{38}$ This kind of narrative was a way to personalize an otherwise impersonal process. It should be observed that personalization as heroes may bring the paradoxical effect of making a model unachievable, and, while presenting it as admirable, dissociates the work of scientists from that of common mortals. To counteract such effect, scientists were described as people who became extraordinary (because of the great contributions they made to humanity), but were normal kids at the beginning. ${ }^{39}$

Even though the Book of Knowledge/The Children's Encyclopedia is composed of dissenting voices, one can perceive the stability of some tendencies, the pervasiveness of some figures, and also some tensions such as between pure and applied science, and between wonder and method, both Gordian knots in the popularization of science.

Another point worth noting is the promise or construction of expectations about the advancement of scientific knowledge. In 1946, the encylopedia presented the 'endless frontier' as the best way, if not the only way, to resolve the problems of humankind. 'Our future happiness as human beings and our future strength as a nation will depend greatly upon whether we continue to develop and train good scientists'. ${ }^{40}$

A comparison between pre- and post-First World War editions shows no significant changes in the view of the social functions of science. The positive image of science was not affected by the Second World War either. On the contrary, we are told that 'the war gave a tremendous forward thrust to scientific thought. People begin to see that science is going to become more and more important. Many governments are taking steps to encourage education in science'. ${ }^{41}$

During the Second World War, Grolier started to publish The Book of Knowledge Annual, an editorial strategy to offer a new publication without having to change much within the twenty volumes of the encyclopedia, updating and complementing the collection that thousands of families had already acquired. From the market's point of view, it seems that the interest of customers had to be continually stimulated and even re-created. As the 1946 introduction stated,

The Book of Knowledge Annual is a survey of the most interesting and important events of the year that has passed, perhaps the sort of survey you might have made if you could have sat on the moon and watched the earth through a big telescope. If you had done that, you would surely have noted that one major subject occupied men's attention more even than war, though it was made to serve the war. The subject, of course, is science. ${ }^{42}$

Science, in this view, was everywhere and everyone should be aware of its effects in daily life and future potentialities. By this 'everywhere', however, we are not suggesting that

38 The Book of Knowledge, op. cit. (10), 1946, p. 4671.

39 'The future of science is wide, and points straight ahead. There is room in it for any and all who want to join up, and there is no end to it.' The Book of Knowledge, op. cit. (10), 1946, p. 7142.

40 The Book of Knowledge, op. cit. (10), 1946, p. 7139.

41 The Book of Knowledge, op. cit. (10), 1946, p. 7137.

42 The Book of Knowledge Annual, 1946, p. 4. 
the same meaning circulated in different cultures and countries where The Book of Knowledge/The Children's Encyclopedia was translated. The meaning of a book may vary depending on the interactions that take place around the circuit of communication. Social, economic and political relations influenced the way it was adapted and read.

\section{The Book of Knowledge beyond borders: a treasure in Latin America}

The Book of Knowledge/Children's Encyclopedia is called El Tesoro de la Juventud (Youth's Treasure) in Spanish, and Tesouro da Juventude in Portuguese. Undated, both first editions were printed in the United States, the Spanish edition around 1919 and the Portuguese edition in the early 1920s. ${ }^{43}$ Until 1950 there were at least four new editions of the Spanish version and three of the Portuguese. But they did not show the same increase in the scientific content found in the English editions of the same period. The few changes that were made were basically updates of the presentations of technologies. As for the historical events that occurred between the editions examined, the only inclusion was the text on the Second World War.

The Spanish version was prepared under the supervision of specialists of different nationalities, who were responsible for the adaptation of the various sections of the book. Led by the Argentine positivist Zeballos, the team comprised the Spanish philosopher Miguel de Unamuno, a former Chilean state minister (Alberto Edwards), a Uruguayan educator (Abel J. Pérez), a Cuban teacher (Ismael Clark y Mascaró), the novelist José Enrique Rodó, an Argentine naturalist (Adolfo de Holmberg), the director of the Mexican National Library (Luis G. Urbina) and the Peruvian jurist Paulino Fuentes Castro. Such an international cooperative effort was not seen in the Portuguese version, exclusively targeted at the Brazilian market. Although written in Portuguese, there was no indication that this version was distributed in Portugal. This difference accounts for the more patriotic overtones of the latter, restricted to one nation only, and for the Hispanic version's challenge of creating a common ground in the history and geography of their regions, which had border conflicts with neighbours who still held conflicting perspectives.

Before discussing local meanings of the different versions, it is worth highlighting some material differences between the editions of both languages. The first refers to size. The Spanish edition consisted of twenty volumes, the same as the English edition, while the Portuguese edition was shortened by two volumes. Corresponding volumes had around 350 pages and contained the same number of articles as well. This variation in size obviously affected the selection of what was retained and what was discarded. Content was also organized in the same forms in equivalent books or sections.

The 'Things we should know' section, which dealt with technologies and how they operated, showed, for example, the extraction of raw materials and the production processes they went through before reaching consumers, highlighting regional activities and national perspectives. So, while the Brazilian edition highlighted coffee production, gemstones and the history of aviation, in which Santos Dumont (not mentioned in the other

43 The only bibliographical information available is that the printing took place in Boston. 

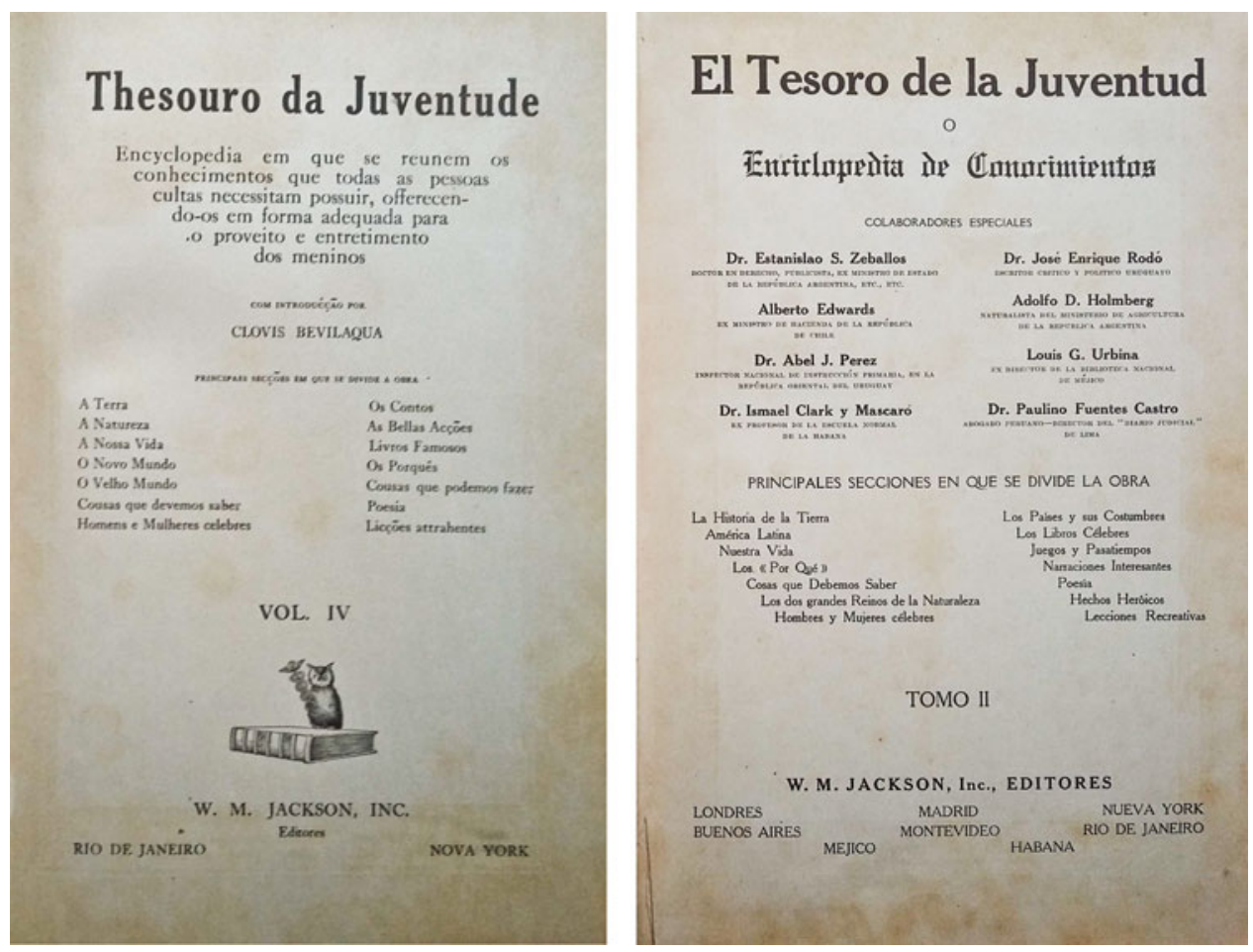

Figure 3. El Tesoro de la Juventud carried the subtitle Enciclopedia de conocimientos (Encyclopedia of Knowledge), while the Brazilian version explained further: '[an] Encyclopedia that brings together the knowledge that all educated people need to possess, offering it in a way suitable for the enjoyment and entertainment of kids'. El Tesoro de la Juventud, vol. 2, frontispiece, c.1919.

versions) was celebrated as the father of aviation, the Hispanic version highlighted mining, sugar production and other sources of wealth of Latin American nations.

The 'School lessons' section was translated as 'Lições atraentes' (Attractive lessons) in Portuguese and as 'Lecciones Recreativas' (Recreational lessons) in Spanish. It is worth noting that one of the aspects of the progressive/active school, which in Latin America is called the Escolanova movement, was the integration of learning experiences inside and outside the classroom intended to ignite students' talents and passions. ${ }^{44}$ While titled 'Lessons', the school focus in these sections was removed, as well as the entries on

44 More than a methodological or pedagogical approach, the Escolanova movement had great importance in the history of Latin American education because of its political dimension, with a strong association between education and democracy. John Dewey's work, in particular, inspired educational reforms in the first decades of the twentieth century. See Inés Dussel and Marcelo Caruso, 'Specters of Dewey in Latin America: some notes on the reception of educational theories', Paedagogica Historica (1998) 34, pp. 375-399; Marcus Cunha, 'John Dewey: the other face of the Brazilian New School', Studies in Philosophy and Education (2005) 24, pp. 455-470. 
arithmetic and calligraphy, while the elementary instructions about music, the arts and the French language were maintained. Unlike the original version and its Portuguese translation, the Spanish edition added introductory lessons for the English language as well. It is worth noting that the absence of these English lessons in the Brazilian version reinforced the tradition, consolidated in previous decades, of France as a cultural model.

As for the 'Things we can do' sections, it should be noted that several sports and games presented showed little acclimatization. Many of them - hockey, golf, baseball - were never part of the Brazilian or South American readers' universe, but it made sense in the circulation of these editions in Latin American countries like Cuba, where the practice of these sports was not rare. The Spanish edition selected theatrical plays for children to enact, as did the original in English, while the Portuguese set replaced these plays with a detailed presentation of scouting in Brazil.

In the sections of the encyclopedia devoted to literature - 'The famous books,' 'The book of stories,' and 'The book of poetry' - only half of the content of the English version, which, incidentally, had not contained Latin American authors, was incorporated into the Spanish and the Portuguese versions. The 'Book of stories' section in the Brazilian edition included regional folk tales and legends, as well as slaves' stories, while one can find, in the Spanish edition, folk tales of Mexico City, novels from Castile, narratives of bloodthirsty Argentine warlords and of a Uruguayan patriot, and stories of colonial Peru, of the founding of Ecuador's capital, of Incan huacas, and so on. The need to include stories of the various Latin American nations where the book would be sold is clear in these examples.

In the Latin American versions, 'The book of poetry' differed significantly from the original. There was almost no common text, except for introductory and explanatory texts such as 'Poetry is the music of words' and 'The different kinds of verse'. The number of poems in the Spanish edition was three times greater than in the Portuguese one. In the Spanish edition we can find more than a hundred poems with Christian themes. It is worth noting that the Bible was not presented in the 'Famous books' section, neither in the original version in English nor in the translated ones. It was mentioned only in its historical and editorial aspects, for example when the encyclopedia presented the lives of Luther or Gutenberg.

In the Portuguese edition world history and geography were divided between 'The book of the Old World' and 'The book of the New World'. The long history of the past belonged to the Old World (Europe, Asia, Africa), but the future and its novelties were on the other side of the Atlantic, in the North, Central and South Americas, with special attention to Brazil. The relationship with its former colonizers - Portugal was not polarized, nor was a Latin identity underlined. In contrast, the Spanish version dealt with history and geography in the section 'Los Países y sus Costumbres' (The countries and their customs) and separately, in an especially dedicated section, 'The book of Latin America'. There was a striking effort to forge a common identity in contrast to the colonial past, underlining the wars of independence and the formation of the republics.

However, natural-science content, distributed within 'The book of the Earth', 'The book of our life' and 'The book of nature' sections, had almost identical texts to that 


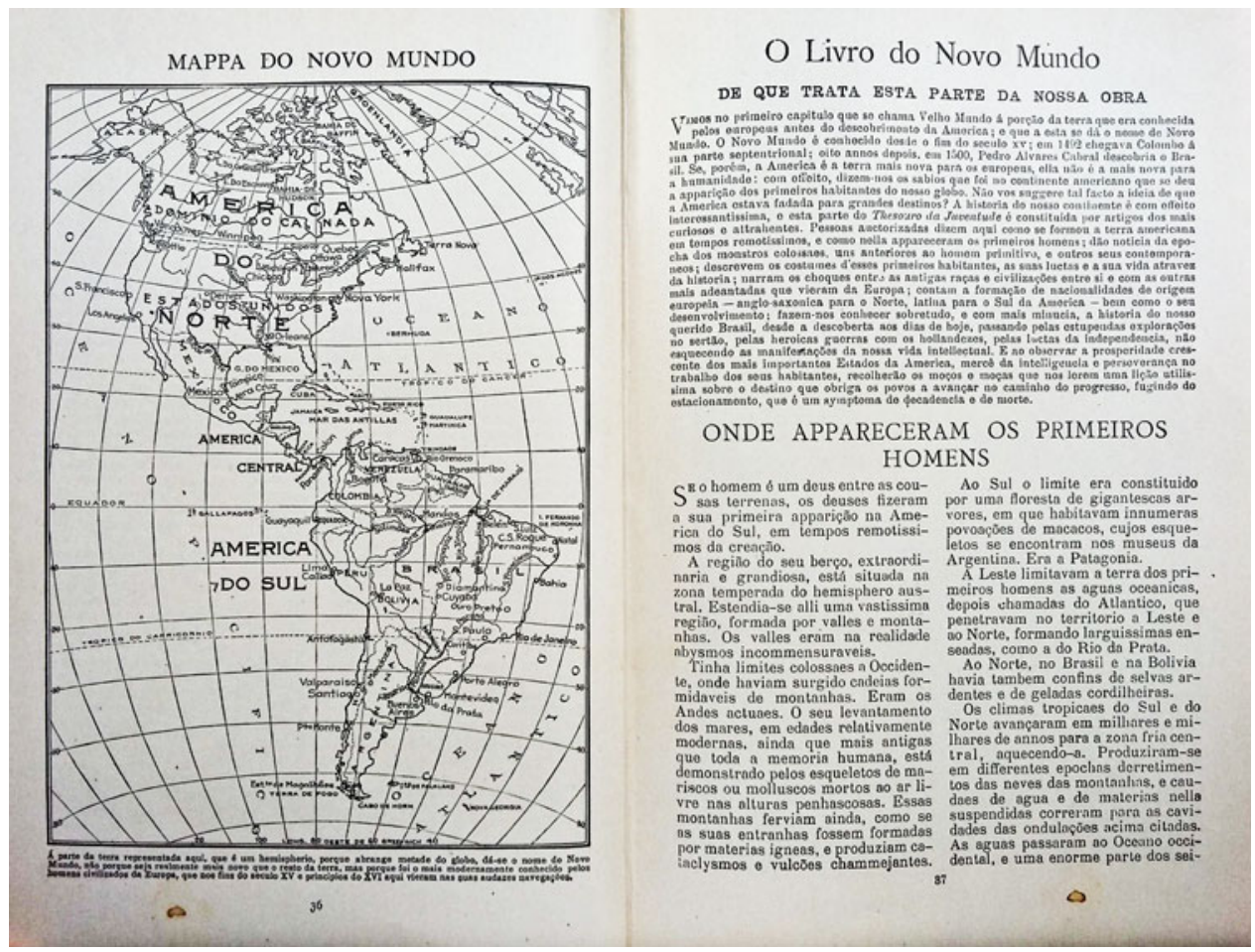

Figure 4. In the version of the encyclopedia sold in Brazil, 'The book of the New World' presented the Americas as a counterpoint to the Old World. Thesouro da Juventude, c.1922, pp. 36-37.

of the original edition in English. The small differences came from increments of local achievements. In addition, the 'Book of wonder' sections of the Portuguese and Spanish versions displayed the same questions, organized in the same sequence, with few substitutions to the original in English. ${ }^{45}$

Such scientific themes were best understood as reflecting the universalist aspirations of the encyclopedias, while other subjects such as biographies, history, religion or law were less easily separable from social interests and cultural contexts. Thus the editors emphasized the importance and effectiveness of scientific development and its results for the progress and development of nations. Conveyed as impartial and useful to all, science was presented in different countries as a patrimony of humanity. The texts aimed to demonstrate how science contributed directly towards the development of civilization and material progress. The learning of scientific knowledge was blended with a cultural project of diffusion of reason and the way of life of modern nations. The introduction of El Tesoro de la Juventud claimed that

45 Maria Clara Ruiz, 'Adaptações locais de um tesouro universal: Análise comparativa de duas versões de uma enciclopédia infanto-juvenil de inícios do século XX', master's disssertation, Universidade Federal de Minas Gerais, Belo Horizonte, 2012. 
the present book is a civilizing work; it is a concurring element, intended to serve and advance the honourable cultural emulation of governments, households and children in South America. As fresh and pure water quenches the thirst and nourishes, it offers the tender spirits copious educational and instructive notions, which will develop their investigative fever and their constant yearning for knowing everything that draws their attention. ${ }^{46}$

The 'Golden deeds' section purported to describe the actions of universally admired 'heroes' for their honour and patriotism. In the three versions, men constituted the vast majority of the 'Men and women'. The few women making an appearance were found in texts about the lives of saints, queens or, more rarely, writers. Additionally, most of the texts were concerned with personalities of European heritage, which reinforced a representation of the colonizing peoples' geopolitical superiority as a standard for civilization. In an interesting analysis of the presence of Latin American nations in the late nineteenth-century World Fairs, Dussel has shown, in the context of international exhibitions, the existence of a tension between exotic and European figures in their self-representations and the difficulty of combining these different nations in a unique pavilion of ex-colonies. ${ }^{47}$ The Thesouro da Juventude presented indigenous people from different ethnic groups of neighbouring countries, but the native peoples of the Brazilian territory were portrayed in engravings and in literary pieces as existing only in the distant past.

The ideals of Western European civilization encompassed multiple aspects, such as standards of fashion, culture, social organization, scientific and technological progress, economic development and, definitively, modernity; and the white race was presented as the one that 'embodies' all those values. The texts also stressed the European 'civilizing mission', the aim to bring forth the best in humans whether by peaceful means or by conquest. This is especially the case of the British Empire, which El Tesoro presents with the following words: 'Here we shall limit ourselves to imparting how such an immense colonial power was formed, overcoming seas and borders, thanks to the steadfast, industrious and entrepreneurial spirit that distinguishes the sons of Great Britain." ${ }^{48}$

As Rossini notes, El Tesoro de la Juventud posited as an undeniable fact of nature the existence of hierarchically ordered human races, betraying latent and sometimes explicit racism. ${ }^{49}$ The visual depictions of white people were far more numerous than those of

46 'El presente libro es una obra civilizadora; es un elemento concurrente, que se propone servir y estimular la honrosa emulación cultural de los gobiernos, de los hogares y de los niños de Sud América. Él, como el agua fresca y pura, que aplaca la sed y alimenta, ofrece a las tiernas inteligencias un caudal de nociones educativas e instructivas que desarrollarán su fiebre investigadora y su constante anhelo por saber todo lo que llama la atención.' El Tesoro de la Juventud, c.1919, p. 10.

47 'Latin American countries did not follow the same pattern when they produced a self-image for the world fairs'. However, 'Education as the expansion of a universal ideal that took national forms was the counterweight they needed to balance their own constructions of cultural singularity'. Inés Dussel, 'Between exoticism and universalism: educational sections in Latin American participation at international exhibitions, 1860-1900', Paedagogica Historica (2011) 47, pp. 601-617, 616.

48 'Aquí nos limitaremos a dar a conocer cómo se ha formado tan inmenso poderío colonial, salvando mares y fronteras, merced al espíritu emprendedor, laborioso y tenaz, que distingue a los hijos de la Gran Bretaña.' El Tesoro de la Juventud, c.1919, p. 4743.

49 Fabian Rossini, 'Lo que leen los chicos: Raza y racismo desde comienzos del siglo XX en la enciclopedia El Tesoro de la Juventud', master's thesis, Universidad de San Andrés, Buenos Aires, 2009. 


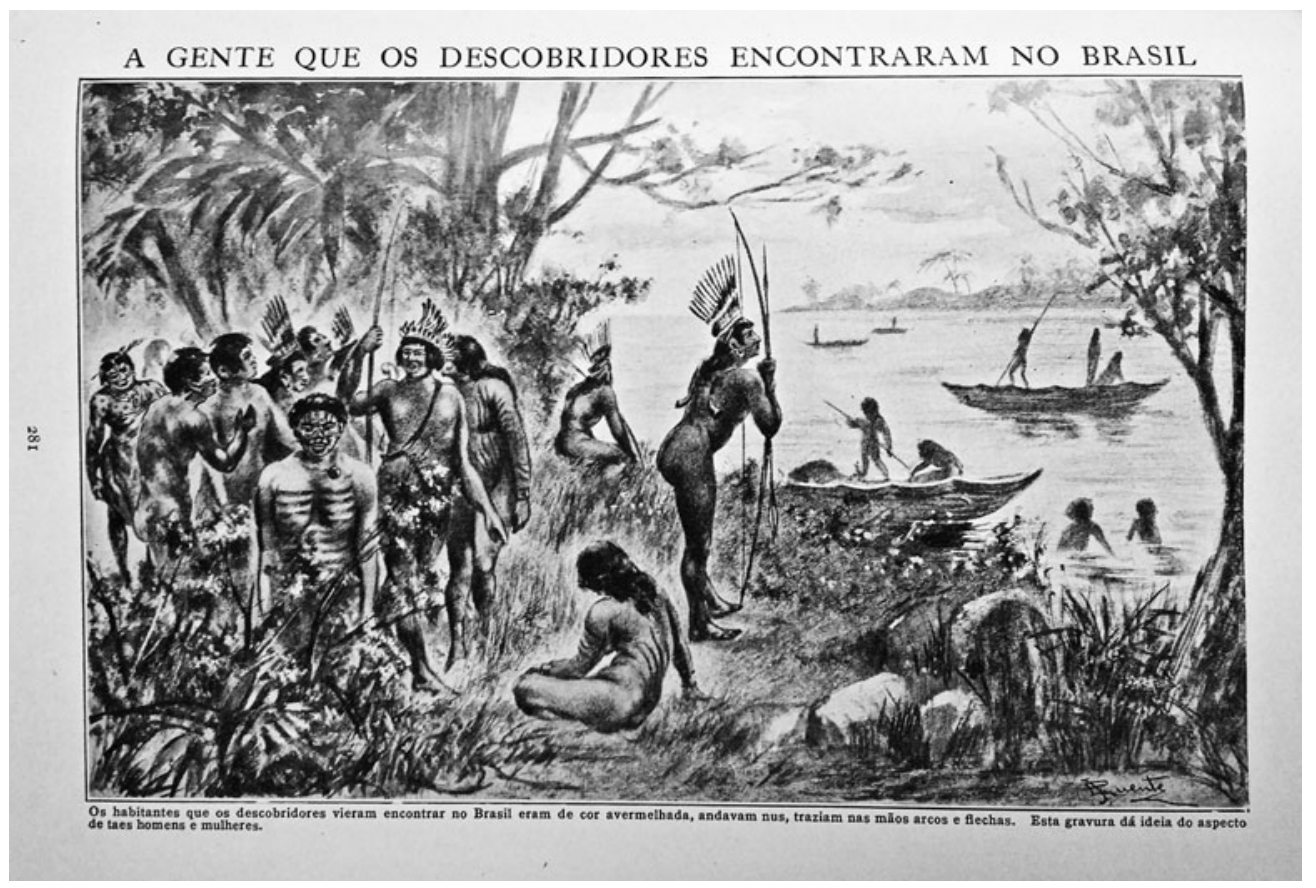

Figure 5. 'People found in Brazil by the discoverers'. Thesouro da Juventude, c.1922, p. 281.

black, indigenous and Asian people. More than 80 per cent of the images were of white people, whereas black people made up less than 2 per cent. ${ }^{50}$ In Latin American countries, where non-whites (blacks, indigenous people or people of mixed heritage) comprise the majority of the population, the circulation of these representations reinforced local racism, but not as explicitly as descriptions of savagery, conservatism, barbarism and physical traits of ugliness and vice focused on non-European peoples (Africans, Asians, indigenous peoples).

In these ways, these countries' advances were associated with the Europeanization of their population:

the character of this population is entirely European, since, as previously stated, the white race has swallowed up Indians and mestizos ... These data demonstrate the Argentine Republic's progress in economic matters, due to its population's homogeneity and the European character of the latter. ${ }^{51}$

50 Rossini, op. cit. (49), p. 41.

51 'Por otra parte, el carácter de esta población es enteramente europeo, pues, como ya dijimos, la raza blanca ha hecho desaparecer por absorción, a los indios y a los mestizos ... Estas cifras demuestran todo el progreso de la República Argentina en materia económica, debido a la homogeneidad de su población y al carácter europeo de la misma.' El Tesoro de la Juventud, c.1919, p. 1478. 
Spanish and Portuguese adaptations of The Book of Knowledge/The Children's Encyclopedia were an editorial success in several Latin America countries from the 1920s until the 1960s. There is not much information available about the number of copies and editions that circulated, but there is evidence that Thesouro da Juventude was considered ideal reading material. It appears in bibliographies of curricula in the 1930s and 1940s, ${ }^{52}$ and in lists of the most-requested books by children in Brazilian public libraries. ${ }^{53}$ It lost its preference when many other competitors entered the market in the 1960s, but for forty years the Thesouro da Juventude had no rivals. However, this editorial success must be qualified. Regional historical conditions gave a particular meaning to the role of this encyclopedia in the popularization of science.

In a society marked by strong socio-economic inequalities, such as Brazil at the time, with a small middle class, reduced education coverage and few public libraries, the Portuguese versions of The Book of Knowledge/The Children's Encyclopedia were, at least in its first editions, restricted to the economic and intellectual elite. Riesco and Rossini show that also in Chile and Argentina this encyclopedia was accessible only to members of the local aristocracy, the majority of whom came from families of immigrants who had achieved a good economic situation, as well as those who had access to school and public libraries where the collection was available. ${ }^{54}$ However, by the 1920 s, these two countries had literacy rates about twice as high as Brazil's. ${ }^{55}$ Thus, compared to the Brazilian situation of the time, their sociocultural inequalities were smaller and the spectrum of their consumer markets was broader. The collection, which in the United States was accessible to the middle class, ${ }^{56}$ in Brazil was affordable only for very wealthy families. Only after 1950 were editions marked down in price and spread to less rich families. Before that, the meaning of buying and reading the Thesouro da Juventude was mainly to be attuned with the modern world, and not to prepare a successful future for the kids, as had been emphasized in the North American publicity, as families who were already wealthy were not concerned about such advancement. For that social group, the learning of scientific knowledge was linked to the cultural project of spreading the values of a rational and modern order among the citizens; promotion of science was seen more as an attempt to change mentality than as a key to economic development. Even keeping the scientific content virtually unchanged, the

52 See Revista de Ensino 1935 (9), p. 118; 1938 (12), p. 287.

53 In line with the progressive school movement, several surveys were conducted in Brazil seeking to know and map the ideals and interests of children. Some of this research, coordinated by the Russian psychologist Helena Antipoff, were published in Revista de Ensino, a journal for teachers of the state of Minas Gerais, demonstrating that Tesouro da Juventude was one of the most accessed work in public libraries. Revista de Ensino 1936 (10), p. 316; 1946 (14), pp. 210-215.

54 Leonor Riesco, 'El maravilloso mundo de El Tesoro de la Juventud: Apuntes históricos de una enciclopedia para niños', Universum (2008) 23, pp. 198-225.

55 UNESCO, 'Education for All Monitoring Report 2006' (2005), at www.unesco.org/education/ GMR2006/full/chapt8_eng.pdf, p. 192, accessed 22 October 2016.

56 During its first five years, The Book of Knowledge set sold for thirty-six dollars. Terms were two dollars a month. Then, a pair of shoes costed around four dollars, and a coat fourteen dollars. As The Book of Knowledge index came only with the last volume, subscribers had a special motive not to stop purchasing the volumes. 
encyclopedia versions gave them new meaning because of the link created with the other themes of the books and the contexts where they circulated.

\section{Conclusion}

Having looked at how The Book of Knowledge/The Children's Encyclopedia delineated science and how the centrality of this knowledge was reinforced in its new editions in English, I then sought to examine how its contents were appropriated in the translations of that encyclopedia into the Portuguese and Spanish languages, which circulated in Latin America in the first half of the twentieth century. These versions were not only translations and adaptations of the original writings, but also adaptations convenient to certain local perspectives, promoting scientific values and technological innovations as the core development and the model of civilization for South American nations. As a multinational enterprise, this encyclopedia contributed to the diffusion of knowledge and values presented as universal, 'the knowledge that all educated people need to possess'. ${ }^{57}$

In addition to the dissemination of scientific knowledge with transnational circulation of information and theories, the communicative characteristics of this encyclopedia have made it an important vehicle for the popularization of science among different social groups and classes, both in the countries where it was first edited and published (Britain and the United States), and in many countries where it was republished and sold.

If we consider as science the transformations and re-creations of knowledge in transit, ${ }^{58}$ or in the process of communication and circulation, the editorial project of this encyclopedia, undertaken by the Grolier Society, can be understood, through its investments, dimensions and innovations, as a good example of big science: involving a large network of collaborators, teams of translators, adapters, distributors, sellers and users, who in turn make their use of it according to their interests and possibilities. As I have shown, the dissemination of information does not imply the circulation of the same meanings. Depending on context, such as the characteristics of a consumer market or national projects, it may be aborted (as seems to have occurred in Russia after the Bolshevik Revolution), be entirely reconfigured, or have its differing symbolic dimensions emphasized, for example to be in tune with modernity.

We have observed that the encyclopedias considered here are particularly well suited to studying the circulation of knowledge and its adaptions, as well as the construction of representations that go along with it. Moreover, we noted that this dissemination of information and learning conveyed a number of forceful representations, condensed in an optimistic and confident view of the future of humanity, as a result of the contribution of science, technology and scientists. The wonder of science was linked to children, who supposedly should incorporate science as achievements of the past and promises of the future.

57 Title page of the Thesouro da Juventude, c.1922.

58 James Secord, 'Knowledge in transit', Isis (2004) 4, pp. 654-672. 


\section{Bernardo Jefferson de Oliveira}

The editorial dimensions of The Book of Knowledge/The Children's Encyclopedia and its versions established the importance of this genre of books in the popularization of science, although its impact on the education system and on general culture is still to be evaluated. Thus history of science should pay attention to different kinds of cultural media that interact with the public view, and they should consider not only new and fashionable ones, but also those that, having declined some generations ago, still echo in public imagery. 